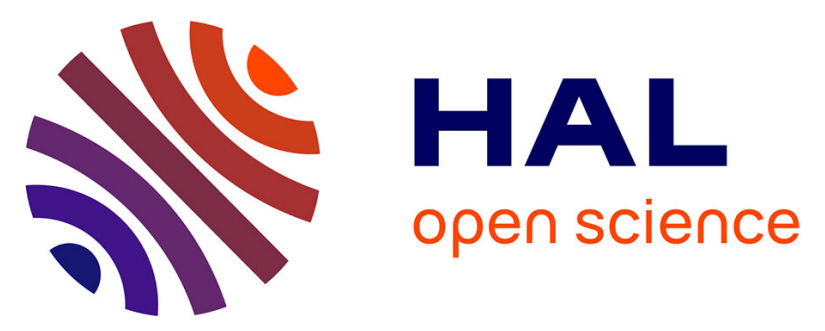

\title{
Rest and Exercise Adaptation of the Right Ventricular Function in Long-Term Left Ventricular Assist Device Patients: a Prospective, Pilot Study
}

\author{
Marie Aymami, Erwan Donal, Julien Guihaire, Alain Le Helloco, Marie
} Federspiel, Elena Galli, François Carré, Bernard Lelong, Céline Chabanne, Hervé Corbineau, et al.

\section{To cite this version:}

Marie Aymami, Erwan Donal, Julien Guihaire, Alain Le Helloco, Marie Federspiel, et al.. Rest and Exercise Adaptation of the Right Ventricular Function in Long-Term Left Ventricular Assist Device Patients: a Prospective, Pilot Study. Journal of Cardiac Failure, 2016, 3 (22), pp.240-241. 10.1016/j.cardfail.2015.12.009 . hal-01260557

\section{HAL Id: hal-01260557}

\section{https://hal-univ-rennes1.archives-ouvertes.fr/hal-01260557}

Submitted on 27 Jan 2016

HAL is a multi-disciplinary open access archive for the deposit and dissemination of scientific research documents, whether they are published or not. The documents may come from teaching and research institutions in France or abroad, or from public or private research centers.
L'archive ouverte pluridisciplinaire HAL, est destinée au dépôt et à la diffusion de documents scientifiques de niveau recherche, publiés ou non, émanant des établissements d'enseignement et de recherche français ou étrangers, des laboratoires publics ou privés. 
REST AND EXERCISE ADAPTATION OF THE RIGHT VENTRICULAR FUNCTION IN LONG-TERM LEFT VENTRICULAR ASSIST DEVICE PATIENTS: A PROSPECTIVE, PILOT STUDY

Short title: Right ventricular adaptation on exercise in LVAD patients

Marie Aymami MD ${ }^{1}$, Erwan Donal MD PhD ${ }^{2,3}$, Julien Guihaire MD PhD ${ }^{1}$, Alain Le Helloco MD ${ }^{2}$, Marie Federspiel MD ${ }^{2}$, Elena Galli MD $\mathrm{PhD}^{2,3}$, François Carré MD $\mathrm{PhD}^{2,3}$, Bernard Lelong MD ${ }^{1}$, Céline Chabanne MD ${ }^{1}$, Hervé Corbineau MD ${ }^{1,3}$, Alain Leguerrier MD ${ }^{1,3}$, Jean-Philippe Verhoye MD PhD ${ }^{1,3}$, Erwan Flécher MD PhD 1,3

1- Thoracic and Cardiovascular Surgery, University Hospital of Rennes, University of Rennes 1, 2 rue Henri Le Guilloux, 35033 Rennes cedex 9, France

2- Cardiology Department, University Hospital of Rennes, University of Rennes 1, 2 rue Henri Le Guilloux, 35033 Rennes cedex 9, France

3- LTSI, INSERM UMR 1099, University of Rennes 1, Campus de Beaulieu Bât 22, 35042 Rennes cedex, France

Corresponding author: Please send correspondence to Marie Aymami, Thoracic and Cardiovascular Surgery, Pontchaillou University Hospital, 2 rue Henri Le Guilloux, 35033 Rennes, France; phone: 0033-299282497; fax: 0033-299282496; e-mail: marie.aymami@chu$\underline{\text { rennes.fr }}$

Keywords: right ventricular function; exercise capacities; left ventricular assist device 
Left Ventricular Assist Device (LVAD) therapy improves survival, functional status, and quality of life in end-stage heart failure (1). However exercise capacity, as assessed by cardiopulmonary exercise testing, remains altered after continuous-flow LVAD implantation (2-4). Right ventricular (RV) function is known to be strongly related to exercise performance in many pathophysiological conditions but has never been investigated in this clinical setting $(5,6)$. We sought to investigate the feasibility of RV assessment by stress echocardiography in long-term LVAD-supported patients in order to characterize the RV during exercise.

All continuous flow LVAD recipients followed at Rennes University Hospital, with at least 6-months of device support (Heartmate-II, Thoratec Corporation, Pleasanton, CA, USA), and with no $\mathrm{RV}$ dysfunction at rest, were eligible for the prospective REVADE study (7). All echocardiographic examinations were performed with a Vivid E9 ultrasound system (GE Medical Systems, Milwaukee, WI, USA). RV dimensions were obtained from a RV-focused apical 4-chamber view at end-diastole (8). The right ventricular fractional area change (RVFAC) was measured as the percentage of area change between RV end-diastolic area and end-systolic area. Tricuspid annular plane systolic excursion (TAPSE) was calculated as the difference between the systolic and diastolic lengths between the RV apex and the tricuspid annulus. RV systolic excursion velocity $\left(S^{\prime}\right)$ was obtained with pulsed Doppler sample volume placed in the lateral part of the tricuspid annulus. The RVOT velocity-time integral (VTI) was measured from pulse-wave Doppler from a parasternal short-axis view. RV flow was calculated as: RVOT VTI x RVOT area $x$ heart rate. RV myocardial performance index (RVMPI) was measured using pulsed Doppler as the ratio of sum of isovolumic contraction and relaxation time over ejection time. Informed consent was obtained from all participants. The study was approved by the local institutional review board and registered on clinicaltrials.gov (NCT 02067455).

The protocol consisted of two exercise tests associated with clinical follow-up: bicycle stress echocardiography ( 45 Watts) and maximal cardiopulmonary exercise testing (CPET). The rotational speed of the device was not modified during the investigations.

Ten patients were prospectively enrolled between April and September 2014 (100\% men, mean age 60.6 years). No adverse event occurred. The table displays the main results of echocardiographic assessment and of cardiopulmonary exercise tests. 
We found a significant increase in RV flow and in the SPAP on slight exercise, while systolic function parameters (TAPSE, 2D RV FAC, $S^{\prime}$, RVMPI) remained unchanged. Mean RV flow improved with a relative increase of $43 \%$ associated with a mean relative increase of $56 \%$ for SPAP. We did not find any difference between rest and exercise in conventional measures of RV systolic function (TAPSE, 2D RV FAC, $\left.S^{\prime}, R V M P I\right)$.

In normal subjects, $\mathrm{S}^{\prime}$ and TAPSE have been shown to significantly increase on maximal exercise.(9) The lack of improvement in our cohort may be due to the submaximal threshold of exercise testing, the blunted response to the increase in load during exercise and to intrinsic cardiomyopathy progression. RVFAC and RVMPI were within normal ranges, whereas TAPSE was slightly reduced and S' severely impaired as compared to normal values. There is growing evidence in the literature that the RV contractile pattern changes after cardiac surgery. Raina et al recommend the use of more global measures of RV function after cardiac surgery or lower normative values when longitudinal measures are used.(10) Our echocardiographic data suggest that the RV flow adapts on slight exercise, even if we cannot say that the systolic function of the RV improves on exercise. Exercise capacity remained altered in LVAD patients. Several factors may explain this finding. First, the relatively fixed cardiac output provided by the continuous-flow LVADs may limit exercise capacity.(2) Indeed, we found a modest increase in pump flow (average $1 \mathrm{~L} / \mathrm{min}$ ) irrespective of the workload sustained ( $45 \mathrm{~W}$ during echocardiography, $80 \mathrm{~W}$ during $\mathrm{CPET}$ ). Peripheral factors may also be involved for patients in whom muscular deconditioning persists.

Limitations: This is a single center pilot study that sought to evaluate the feasibility of RV function assessment on exercise with stress echocardiography so the overall number of patients included is small, limiting our ability to detect differences between observations at rest and on exercise.

In conclusion, exercise capacities of LVAD patients remain limited. In stable LVAD patients, with no RV dysfunction at rest, we could demonstrate an increase in RV flow on slight exercise. The limitation seems to originate from the limited ability of the continuous flow device to significantly increase its flow, but also to the chronic insufficiency of the peripheral muscle to extract oxygen, which is likely to persist after LVAD implantation. 


\section{REFERENCES}

1. Rogers JG, Aaronson KD, Boyle AJ, et al.: Continuous flow left ventricular assist device improves functional capacity and quality of life of advanced heart failure patients. Journal of the American College of Cardiology 2010;55:1826-34.

2. Nahumi N, Morrison KA, Garan AR, Uriel N, Jorde UP: Peak exercise capacity is a poor indicator of functional capacity for patients supported by a continuous-flow left ventricular assist device. The Journal of heart and lung transplantation : the official publication of the International Society for Heart Transplantation 2014;33:213-5.

3. Dunlay SM, Allison TG, Pereira NL: Changes in cardiopulmonary exercise testing parameters following continuous flow left ventricular assist device implantation and heart transplantation. Journal of cardiac failure 2014;20:548-54.

4. Camboni D, Lange TJ, Ganslmeier P, Hirt S, Flörchinger B, Zausig Y, et al..: Left ventricular support adjustment to aortic valve opening with analysis of exercise capacity. Journal of cardiothoracic surgery 2014;9:93.

5. Di Salvo TG, Mathier M, Semigran MJ, Dec GW: Preserved right ventricular ejection fraction predicts exercise capacity and survival in advanced heart failure. Journal of the American College of Cardiology 1995;25:1143-53.

6. Haddad F, Doyle R, Murphy DJ, Hunt SA: Right ventricular function in cardiovascular disease, part II: pathophysiology, clinical importance, and management of right ventricular failure. Circulation 2008;117:1717-31.

7. https://clinicaltrials.gov/ct2/show/NCT02067455?term=REVADE\&rank=1

8. Rudski LG, Lai WW, Afilalo J, Hua L, Handschumacher MD, Chandrasekaran K, et al.:

Guidelines for the echocardiographic assessment of the right heart in adults: a report from the American Society of Echocardiography endorsed by the European Association of Echocardiography, a registered branch of the European Society of Cardiology, and the 
Canadian Society of Echocardiography. Journal of the American Society of Echocardiography : official publication of the American Society of Echocardiography 2010;23:685-713; quiz 86-8.

9. Almeida AR, Loureiro MJ, Lopes L, Cotrim C, Lopes L, Repolho D, et al.:

Echocardiographic assessment of right ventricular contractile reserve in patients with pulmonary hypertension. Rev Port Cardiol 2014;33:155-63.

10. Raina A, Vaidya A, Gertz ZM, Susan C, Forfia PR: Marked changes in right ventricular contractile pattern after cardiothoracic surgery: implications for post-surgical assessment of right ventricular function. The Journal of heart and lung transplantation : the official publication of the International Society for Heart Transplantation 2013;32:777-83. 
Table 1. Right heart parameters and ventilatory parameters at rest and on exercise.

\begin{tabular}{|c|c|c|c|c|c|c|}
\hline & Rest & $\begin{array}{c}\text { Exercise } \\
(45 W)\end{array}$ & p & $\begin{array}{c}\text { Feasibilit } \\
\text { y of } \\
\text { measures } \\
\text { at rest }\end{array}$ & $\begin{array}{l}\text { Feasibilit } \\
\text { y of } \\
\text { measures } \\
\text { on } \\
\text { exercise }\end{array}$ & $\begin{array}{c}\text { Peak } \\
\text { exercise }\end{array}$ \\
\hline \multicolumn{7}{|c|}{ Echocardiographic parameters } \\
\hline $\begin{aligned} \text { RV dimensions }(\mathbf{m m}) \\
\begin{aligned} & \text { basal } \\
- & \text { mid-cavity } \\
- & \text { longitudinal }\end{aligned}\end{aligned}$ & $\begin{array}{c}39.3 \pm 6 \\
4 \\
34.7 \pm 6 \\
6 \\
65.2 \pm 8 \\
2\end{array}$ & $\begin{array}{c}40.9 \pm 11 \\
3 \\
35.5 \pm 5.9 \\
64.0 \pm 9.4\end{array}$ & $\begin{array}{l}\text { NS } \\
\text { NS } \\
\text { NS }\end{array}$ & $\begin{array}{l}9 / 10 \\
9 / 10 \\
9 / 10\end{array}$ & $\begin{array}{l}8 / 10 \\
8 / 10 \\
8 / 10\end{array}$ & $\begin{array}{l}- \\
- \\
-\end{array}$ \\
\hline RV FAC (\%) & $0.4 \pm 0.1$ & $0.4 \pm 0.1$ & NS & $9 / 10$ & $8 / 10$ & - \\
\hline RV flow (L/min) & $3.8 \pm 1.4$ & $5.6 \pm 2.5$ & $\begin{array}{c}0.0 \\
3\end{array}$ & $9 / 10$ & $7 / 10$ & - \\
\hline SPAP $(\mathrm{mmHg})$ & $\begin{array}{c}32.3 \pm 4 \\
9\end{array}$ & $\begin{array}{c}51.4 \pm 13 \\
8\end{array}$ & $\begin{array}{c}0.0 \\
1\end{array}$ & $8 / 10$ & $7 / 10$ & - \\
\hline TR (14) & $0.9 \pm 0.7$ & $1.4 \pm 0.6$ & NS & $9 / 10$ & $7 / 10$ & - \\
\hline RIMP & $0.4 \pm 0.1$ & $0.3 \pm 0.0$ & NS & $7 / 10$ & $5 / 10$ & - \\
\hline TAPSE $(\mathrm{mm})$ & $\begin{array}{c}13.9 \pm 1 \\
6\end{array}$ & $14.4 \pm 2.4$ & NS & $9 / 10$ & $8 / 10$ & - \\
\hline $\begin{array}{l}\text { RV systolic excursion } \\
\text { velocity } S^{\prime}(\mathrm{cm} / \mathrm{s})\end{array}$ & $6.3 \pm 1.7$ & $6.7 \pm 1.4$ & NS & $9 / 10$ & $7 / 10$ & - \\
\hline \multicolumn{7}{|c|}{ Ventilatory parameters } \\
\hline $\begin{array}{l}\text { HR (bpm) } \\
\% \text { predicted }\end{array}$ & $\begin{array}{c}68.1 \pm \\
10.4 \\
-\end{array}$ & $\begin{array}{c}96.9 \pm 19 \\
5 \\
-\end{array}$ & - & - & - & $\begin{array}{c}112.3 \pm \\
19.5 \\
69.8 \pm \\
10.4\end{array}$ \\
\hline Pump flow (L/min) & $\begin{array}{c}4.7 \pm \\
0.9\end{array}$ & $5.7 \pm 0.9$ & - & - & - & $5.7 \pm 1.0$ \\
\hline
\end{tabular}




\begin{tabular}{|l|c|c|c|c|c|c|}
\hline Workload (W) & - & - & - & - & - & $80.6 \pm 23$. \\
\% predicted & & & & & & 2 \\
& & & & & & $50.1 \pm 12$. \\
& & & & & & 2 \\
\hline Peak VO, (ml/kg/min) & - & - & - & - & - & $12.6 \pm$ \\
\% predicted & & & & & & 2.5 \\
& & & & & & $49.2 \pm$ \\
\hline Slope VE/VCO 2 & - & - & - & - & - & $39.4 \pm$ \\
\hline AT (ml/kg/min) & & & & & & 8.2 \\
\% predicted & - & - & - & - & - & $9.3 \pm 0.9$ \\
& & & & & & $34.6 \pm$ \\
\hline
\end{tabular}

RV : Right Ventricle; RVFAC : Right Ventricular Fractional Area Change ; SPAP : systolic pulmonary arterial pressure; TR : tricuspid regurgitation; RIMP : right ventricular index of myocardial performance; TAPSE : Tricuspid Annular Plane Systolic Excursion; HR : heart rate; VO2 : oxygen consumption; slope $\mathrm{VE} / \mathrm{VCO}_{2}$ : ventilator efficiency slope; $\mathrm{AT}$ : anaerobic threshold 